\title{
Growth of undoped and Te doped InSb crystals by vertical directional solidification technique
}

\author{
D B GADKARI*, K B LAL and B M ARORA ${ }^{\dagger}$ \\ Department of Physies, Mithibaj College, Mumbai 400 056, India \\ tDepartment of Physics, University of Bombay, Mumbai 400098 , India \\ FSSE Group. Tata Institule ol Fundamental Research, Mumbaj 400005, India \\ MS received 18 April 1996; revised 20 Februlary 1998
}

\begin{abstract}
We have successfully grown high mobility mopod and l'e doped InSb crystals of size 10 m12 $\mathrm{mm}$ dia. and $60 \mathrm{~mm}$ length under inert argon atmosphere in closed quartz ampoules, by vertical directioual solidification (VDS) technique. The crystals showed predominautly (220) orientation along the growth axis. The surface defects, snch as yoids were reduced drastically by selecting proper lowering rate, rotational speed and cone angle of the ampoule. The high mobility and quality crystals were obtained with the ampoule conical angle less than $20^{\circ}$, Jowering rate $5 \mathrm{~mm} / \mathrm{h}$, and rotational speed $10 \mathrm{rpm}$.
\end{abstract}

Keywords. InSb crystals; directional solidification; quartz ampoule; cone angle; Hall measurement; inert atmosphere.

\section{Introduction}

InSb crystals are useful for infrared decctors in $3-5 \mu \mathrm{m}$ wavelength range (Chen et al 1992). This material is also of increasing interest for large area detector arrays (Rayners et at 1993), high speed devices (Asauskas 1980) and optoelectronics devices (Baranski 1990). For epitaxial growth of lnAsSb on InSb (Eagen et at 1994), substrates of high qualty are required (Ohaski 1986; Lee et al 1993; Michel et al 1994). There have been reports of InSb bulk crystal growtl using methods such as Czochralski (Witt ef al 1968; Lin and Kou 1995), Bridgman (Kim 1978: Mulski and Neumann 1982), zone refining (Garantet et al 1995), vertical gradient (Strauss 1959; Potard 198I; Jung et al 1991) and centrifuge (Weber et al 1990; Derabail and Wilcox 1992; Zhou et at 1993). We have underaken the growlh of uncoped and doped bulk InSb crystals by vertical directional solidification (VDS) technique in conical quartz ampoule without using any seed. The VDS is a simple and suitable method for obtaining good yuality InSt single crystals. To reduce the $\mathrm{Sb}$ loss related problem, the growth is done in closed ampoule and under optimization of inert atmosphere of argon. This paper reports the details of experiments carried out under various growth conditions such as cone angle of ampoule, lowering rate, rotation speed and inert gas for high quality single crystal growth withoul seed. As grown crystals are p-type while Te has been used for growing $n$-rype doped crystals.

*Author for comespondence

\section{Experimental}

\section{2,1 Crystal growth}

We performed the growth of InSb crystals in a vertical growth system by directional solidilication (VDS) (Gadkari et al 1994). The system consists (see figure 1) of a vertical single zone resistance furnace. Quartz tube of $10 \mathrm{~cm}$ dia. and $100 \mathrm{~cm}$ length was used as the growth chamber. The tube was closed at both ends by end caps with Wilson seal arrangements for gas inler and ouflet. Water circulation was used for cooling the seals. Thermocouple ( $\mathrm{Cr}-\mathrm{Al}$ ) was inserted from the bottom end of guartz tube for measurement of temperature inside the growth chamber. High purity In $(6 \mathrm{~N}), \mathrm{Sb}(6 \mathrm{~N})$ and Te $(6 \mathrm{~N})$ were used as source materials. $9.7 \mathrm{~g}$ In and $10.3 \mathrm{~g}$ Sb in stoichiometric composition were filled in quartz ampoule of $10-12 \mathrm{~mm}$ in dia. and $100 \mathrm{~mm}$ in length with conical end on one side. Ampoules of various cone angles ranging from $15-70^{\circ}$ were used in the growth experiments. Initially, growth was tried in open ampoule with flowing $N_{2}$ atmosphere. However, the resulting crystal was of poor quality. Subsequently growth was done in sealed amponle and two yariations of the procedure were used. In one case, the ampoule was sealed in vacuum and in the second case the ampoule was backfilled with argon before sealing. Growth of doped erystals was done by mixing $\mathrm{Te}$ dopant in the charge before sealing the ampoule for the directional solidification. Ampoule can be moved vertically as well as rotated in the growth chamber. The InSb charge was melted (see figure 2) by keeping the ampoule in the 
constant tenperature of the furnace by raising the ternperatmre to $800^{\circ} \mathrm{C}$. This temperature was maintained for $10 \mathrm{~h}$ for synthesis and homogeneous mixing of the sontce materials. For the growth, the ampoule was lowered to the gradient zone of the furnuce where the temperature was in the range $575-650^{\circ} \mathrm{C}$ and kept in this zone for $10 \mathrm{~h}$ for prolonged heating for thermal stabilization in the melt prior to starting the growth. The growth was done by further lowering the ampoule in the gradient zone. Difterent lowering rutes in the range $5-10 \mathrm{~mm} / \mathrm{h}$ were used. Further the rotation speed was varied in the range 10-30 tpm. After completion of the growth, the Insb ingot was anoealed at a constant tcmperature of $200^{\circ} \mathrm{C}$ for about $18-24 \mathrm{In}$ prior to its removal from the growth chamber. The typicat growh profile is shown in figure 2. In good quality growth, the ingot can be removed from the quartz ampoule easily showing that the melt does not stick to the wall of the ampoule. As such the dianeter of the grown ingot is slightly smaller than the internal dianeter of the ampoule.

\subsection{Sample characterization}

Substrates of thickness about $500 \mu \mathrm{m}$ were cut perpendicular to the growth axis. These wafers were cleaned and lapped by $5 \mu \mathrm{m}$ carborundum powder. Fulther polishing of the wafers was done mechanically by using 0.3 and $0.05 \mu \mathrm{m}$ alumina abrasive to mirror finish. We tried also chemi-mechanical polishing using $5 \%$ brominemethanol solution and similar fesults were observed. Wafers were cleaned in warm TCE, acetone and methanol of electronic grade. These waters were then used for various characterizations e.g. (i) the Xrray diffriction for olientation determination and XRD patterns were recorded with step angle $0.02^{\circ}$ and $0.5 \mathrm{~s}$ step time on JEOL JDX-8030 for $35 \mathrm{KV}$ and $25 \mathrm{~mA}$, (ii) growth morphology, and (iii) electrical transport properlies by Hall measurements (Van der Pauw J958; Look 1990). The EDAX measurements were used to identify the composition in the defect regions.

\section{Results and discussion}

\subsection{Unsealed ampoule}

Early gowth experiments were perfornted in unsealed anpotes in flowing $N_{2}$. Ingots were grown by using ampoules with 4 different cone angles from $50^{\circ}-70^{\circ}$. In all cases, growth showed severe distribulion of voids on the surfaces. The XRD pattern of the InSb substrates cut from these ingots showed large FWHM for XRD peaks (see table l), indicating large heterogeneities and grais boundaries which may be due to polyerystaline growth.

\subsection{Sealed ampoule}

Since the open ampoule growth was of poor quality, the growths were carried out in ampoule with cone angle less than $30^{\circ}$. The source materials In and S6 inside ampoules were alternately evacuated and flushed with argon 10 times prior to vacuum sealing $\left(10^{-5}\right.$ torr), and growth was carried out at lowering rate $10 \mathrm{~mm} / \mathrm{h}$ and rotation speed $30 \mathrm{rpm}$. Ingots were void free, $10 \mathrm{~mm}$ dia. and $60 \mathrm{~mm}$ length (figure 3). XRD messurements

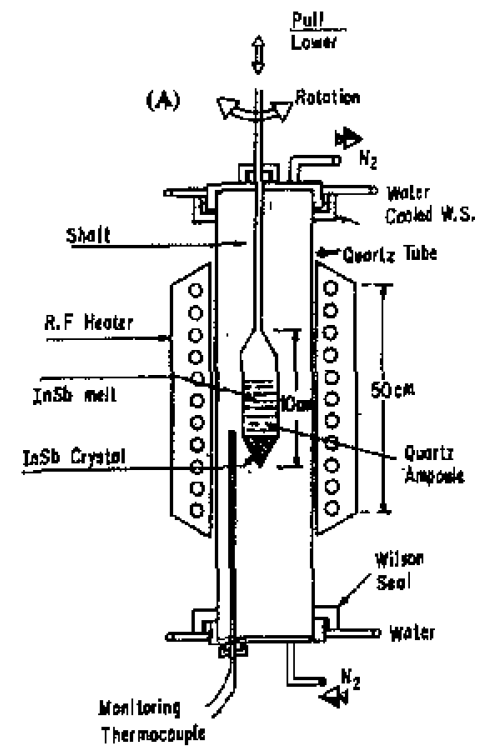

Figure 1. A. Schemalic diagram of the growh system and B. temperature profile of the furtace.
(B)

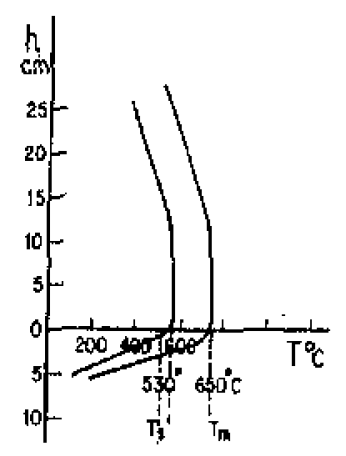

Figure 2. The orystal growth temperature versus time graph atter optinizing growh conditions. The temperature is specitied at the conical tip of the ampoule. 
Table 1. Cone angles of atrpoules and Hall measurements at $300 \mathrm{~K}$.

\begin{tabular}{|c|c|c|c|c|c|c|c|}
\hline $\begin{array}{l}\text { Growth } \\
\text { no. }\end{array}$ & Crystiz I & $\begin{array}{l}\text { Ampoule } \\
\text { ambient }\end{array}$ & $\begin{array}{l}\text { Cons } \\
\text { angle }\end{array}$ & $\begin{array}{l}\text { Semicond. } \\
\text { lype }\end{array}$ & $\begin{array}{c}\text { Mobility } \\
\left(\mathrm{cm}^{2} / \mathrm{V} \cdot \mathrm{sec}\right)\end{array}$ & $\begin{array}{c}\text { RHI } \\
\left(\mathrm{cm}^{3} / \text { coulomb }\right)\end{array}$ & $\begin{array}{c}\text { FWHM }(220) \\
\text { (arcsec) }\end{array}$ \\
\hline 3 & Insb p3 & $\mathrm{A}$ & 64 & $\mathrm{p}$ & - & - & 1140 \\
\hline 4 & Inst p4 & A & 60 & $p$ & - & - & 1290 \\
\hline 5 & Inst p5 & A. & 50 & p & - & - & 1780 \\
\hline 6 & $\operatorname{InS6~p6~}$ & $\mathrm{A}$ & 54 & $\mathrm{p}$ & - & - & 1740 \\
\hline 7 & $\ln S b p^{7}$ & B & 30 & $\mathrm{P}$ & - & - & 1680 \\
\hline 8 & $\ln S \mathrm{~b} \mathrm{P}^{-1}$ & C & 25 & $\mathrm{p}$ & 3900 & $-39 \cdot 6$ & 580 \\
\hline 9 & $\operatorname{In} S \mathrm{P}-\mathrm{R}$ & $\mathrm{C}$ & 22 & $p$ & 3500 & -41.5 & 560 \\
\hline 10 & $\ln \$ b \quad n-1$ & C & 25 & n & 3400 & -0.35 & 482 \\
\hline 11 & Insb o- $R$ & $\mathrm{C}$ & 25 & n & 3145 & -0.49 & 455 \\
\hline 12 & $\int_{11 S b} p_{2-4}$ & $\mathrm{D}$ & 18 & $p$ & 42000 & -143.0 & 285 \\
\hline 13 & Inst $112-4$ & $\mathrm{D}$ & 16 & n & 27000 & $-10 \cdot 6$ & 260 \\
\hline 12 & Insts $p^{2}-12$ & $\mathrm{D}$ & 18 & $\mathrm{p}$ & 55000 & -165 & 255 \\
\hline 13 & $\operatorname{lnSt}$ เi2-12 & $\mathrm{D}$ & 16 & n & 25600 & $-11 \cdot 5$ & 235 \\
\hline
\end{tabular}

A. Open ampoulc tlowing $N_{7} ; B$, ampoule closed in vacuum $\left(10^{-5}\right.$ torr) without argon flushing; $C$, umpouic prior to vacuun sealing $\left(10^{-\bar{x}}\right.$ torr) was tlushed by argon', $\mathrm{D}$, ampoule closed under aroon pressuce (100 torr). Measurements were laker on two samples of growh nos 12 and is trom different places.

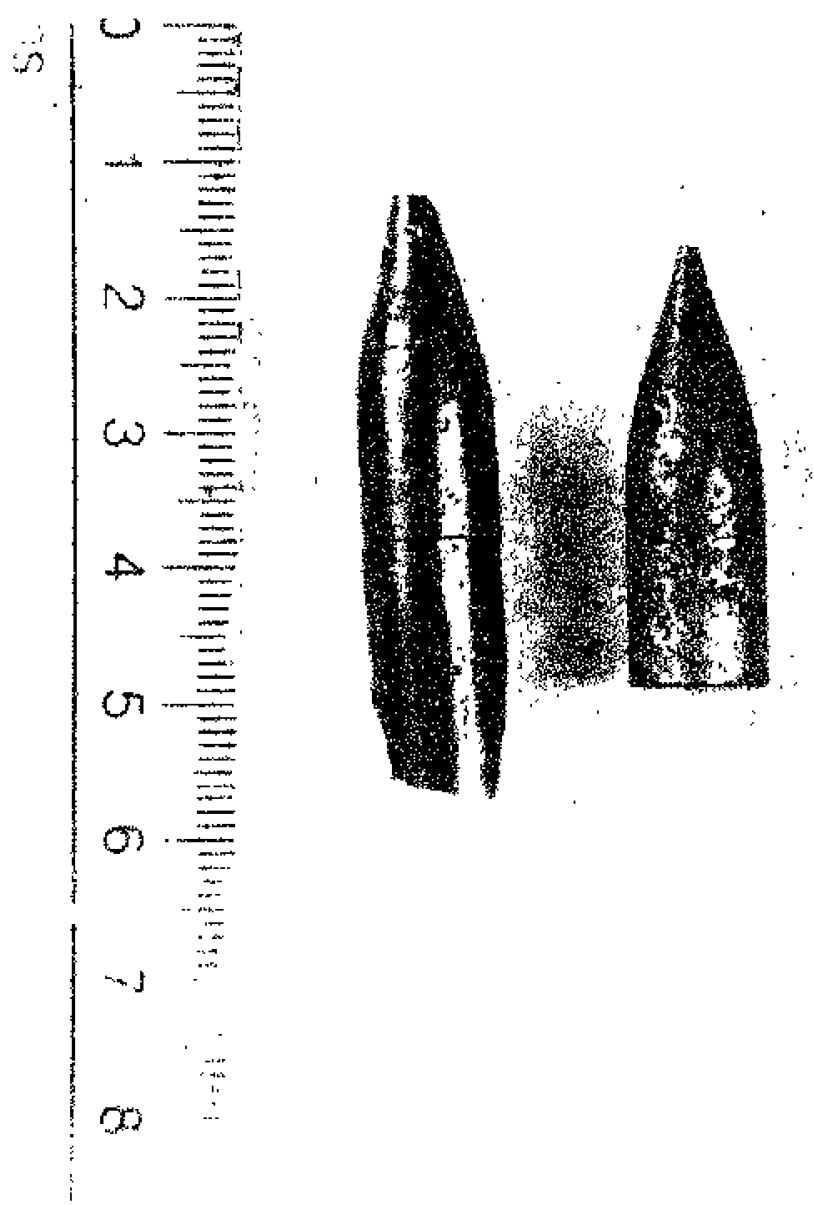

tigure 3. The growlh of unfoped ingots performed by sealing the ampoules in vacium (growth nos 8-9).

from powder of the as grown material showed agreement with ASTM data and JCPDS card no. 6-208 (Int. diff.

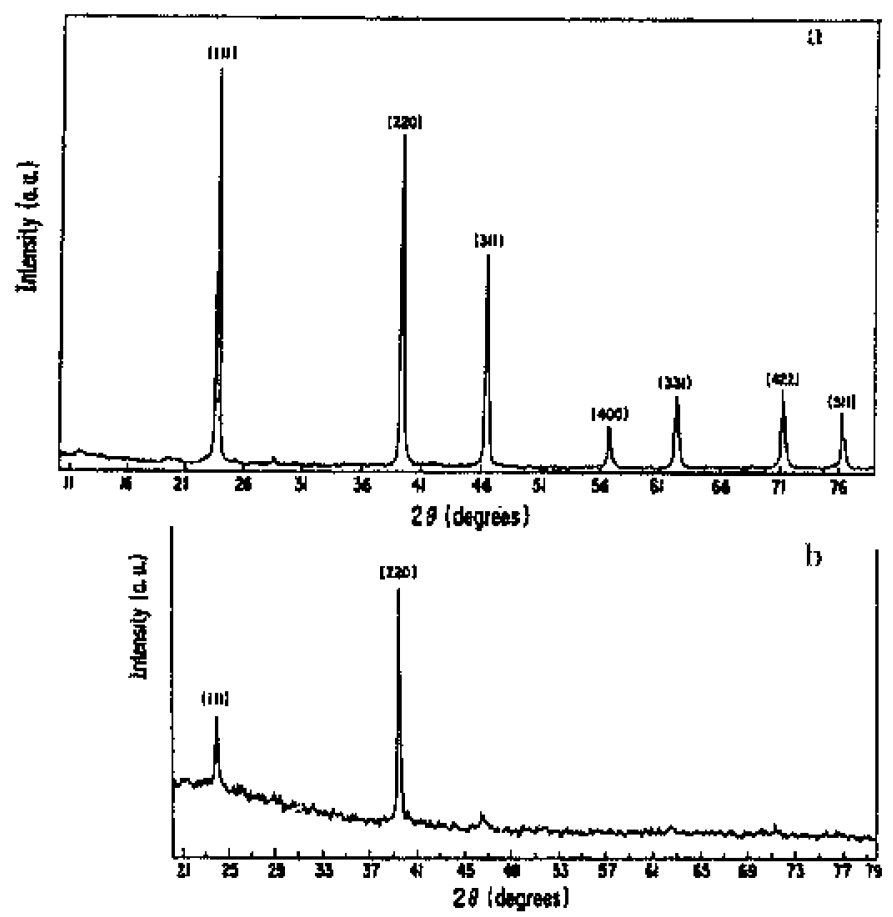

Figure 4. a. XRD paltern ol the powder crushed Jrom grown InSb ingots and $b$. XRD patem of as substrate cut perpendicular lo the growth axis.

(lata 1994) (see figure 4a). Wafers prepared from the ingots showed prominent reflection for (220) orientation (see figure $4 b$ ). Sharp peaks of the XRD (table 1) showed improved crystallinity of the InSb ingots. Etching of polished wafers revealed regions rich in $S b$ as probed by EDAX. The etching of the undoped InSb substrate showed growth morphology such as conical etch pits, eutectic microstructures and ribs. While, heavily Te doped 


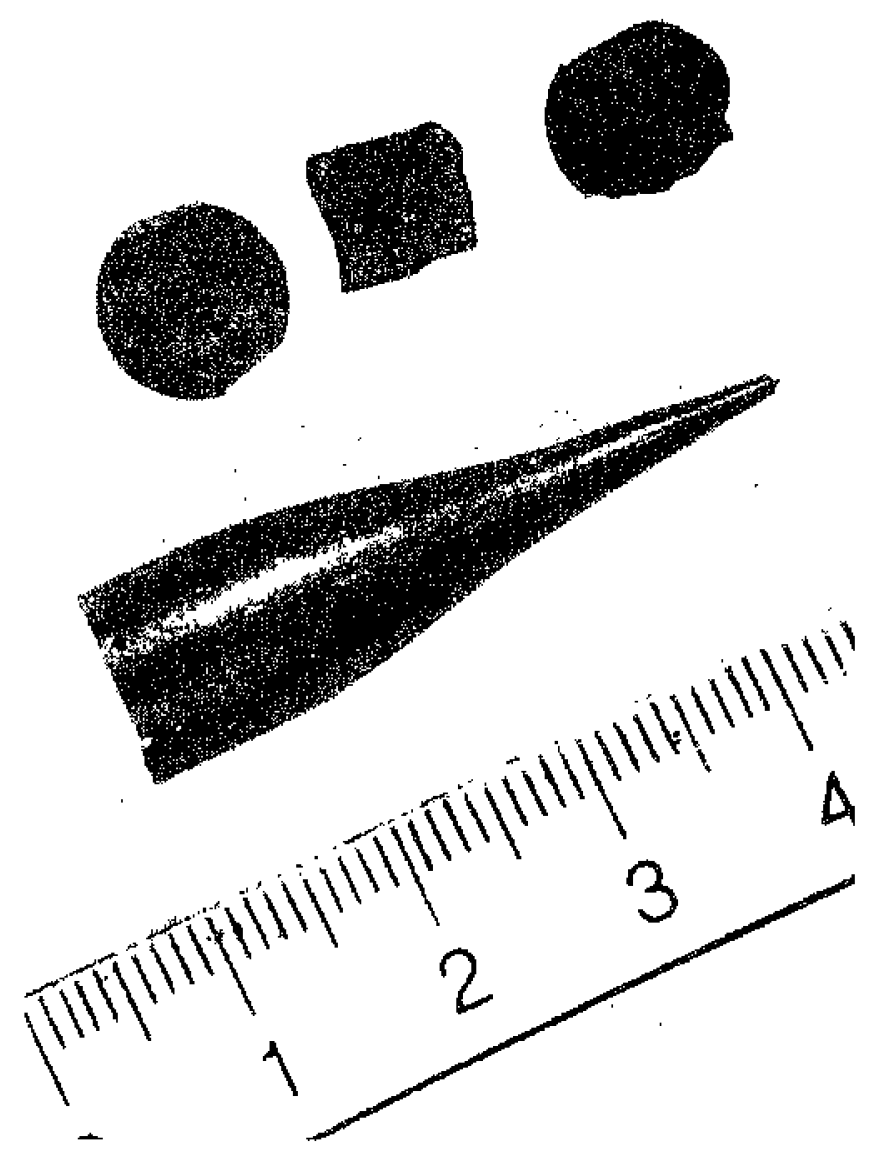

Figure 5. Magnified photograph of Te doped ingots willi substates (growlh no, 13).

substrates (Gadkari et $a$ l995) showed absence of eulectio features but defeets like striations, band formation, mictocracks and precipitate were observel.

Hall-Van der Pauw measurements, the undoped and Te doped samples at $300 \mathrm{~K}$ showed low mobility of $3900 \mathrm{~cm}^{2} / \mathrm{N}$.sec and $3400 \mathrm{~cm}^{2} / \mathrm{V}$. sec respectively. From these observations we concluded that the crystals contained excessive defects. In order to overcome this problem. we did next series of experiments in anpoules closed under Ar pressure.

\subsection{Sealed ampoules with inert atmosphere}

In this modified procedure, the source materials were at first evacuated and tlushed with argon 10 times. Finally, the ampoule was backfilled with argon at 100 torr and sealed. All the ampoules used in the experiments had cone angle less than $20^{\circ}$, and growth was done at lowering rate of $5 \mathrm{~mm} / \mathrm{h}$ and rotational speed $10 \mathrm{rpm}$. As grown ingots were free from voids (figure 5) with smooth surface. The ingots came out easily from the ampoules which showed that the melt did not stick to the walls of the ampoules. Ingots surface were observed to be more shiny in conical region than the cylindrical regtons as seen in figure 5 .

$X$-ray diffraction measurements on the wafers cut from these ingots showed prominent (220) reflection and excelletal agrement with the ASM data mentioned earlier. Further as seen from table 1, the FWHM had improved further as compared to the growth done in the evacuated ampoule. Improvement in the quality of the crystal grown under argon atmosphere was also seen from the Hall toeasurements. Undoped crystals were $p$-rype with mobility reaching a value $55000 \mathrm{~cm}^{2} N$ sec at room teniperature. The low $(20 \mathrm{~K}$ ) temperature Hall mensurement on this sample showed doping concentration $\left(-1 \times 10^{1 / 1} \mathrm{~cm}^{-3}\right)$ which shows reduction in the background defects by using this procedure. The Te doped materials are also of better quality and show significant incrcase in mobility from $26000 \mathrm{~cm}^{2} / V$ sec at room temperature to $29000 \mathrm{~cm}^{2} / \mathrm{V} . \mathrm{sec}$ at $40 \mathrm{~K}$ with the donor concentiation of $6 \times 10^{17} \mathrm{~cm}^{-3 .}$.

\section{Conclusions}

Nearly pertect single bulk crystal of InSb of high quality and degree of crystallinity have been grown from the melt by the VDS techrique. Our experiments show the following.

(I) The wafers cut from the ingots show prominent (220) reflection indicating growtl of nearly single crystal without seed.

(II) Maintainiog inert argon atmosphere in the closed quartz ampoule is very crucial for growing high nobility InSb crystals. Other optimized growth parameters ate (i) ampoule loweriog rate $5 \mathrm{~mm} / \mathrm{h}$, (ii) totation speed 10 rpm and (iii) conical angle less than $20^{\circ}$. Good quality ingots of 10-12 mm dia, $60 \mathrm{~mm}$ in length and $20 \mathrm{~g}$ wejght have been grown by VDS technique in closed quartz ampoule.

(aI) Undoped InSb is $p$-type, A very high Hall mobility $-55000 \mathrm{~cm}^{2} / \mathrm{V}$ sec has been achieved in the optimized growth.

(IV) Te doped $n$-type malerial with doping concentration $6 \times 10^{17} \mathrm{~cm}^{-3}$ and Hall mobility $26000 \mathrm{~cm}^{2} / \mathrm{V}$ sec at $300 \mathrm{~K}$ have been grown.

These results indicule the effectiveness of vertical directional solidification method for the growth of high quality. uniform internal structure and high mobility InSb bulk crystals.

\section{Acknowledgements}

The althors thank Dr A J Singh, BARC, Mumbai and Prof. K S Chandrasekharan, Emeritus Professor, Maduraj University, for useful suggestions and discussion. One 
of the authors (DBG) wishes to thank Principal, Mithibai College, Mumbai for encouragement and to the SSE Group, TIFR for assistance in XRD, electrical, optical and SEM measurements.

\section{References}

Asauskas R, Dobro Volskis and Krolkus A 1980 Sov. Plys. Senicond. 141377

Baranski P I, Gorodnichi O P and Shcvehonko V V 1990 Infrared Phw. 3059

Byueng-Su Yoo, Mark A McKec, Sang -Gi Kim and El-Hang Lee 1993 Solid State Commum. 88447

Chen L P, Lou J J, Liu T H, Pang Y M and Yang S J 1992 Solid State Electron. 351081

Derabail $\mathrm{R}$ and Wilcox W $\mathrm{R} 1992$ J. Cryst. Growth 119 98

Eager R J et al 1994 Semicond. Sri. Terhnol. 91591

Gadkari D 5, Lal K B and Arora B M 1994 Solid Siate Phys. (India) C37 198; DAE Symp. (Jajpur: Rajasthan Univ)

Gadkasi D B, Lal K B. Singl A I and Arora B M 1995 Proc. VI hational seminar on crystal growh (Madras: Anna Univ.) p. 34

Gadkari D B, Lal K B, Shah A P and Arora B M 1995 Solid State Phys. (India) C38 148; DAE Symp. (Calcutta: ACS) .
Garanuet J P, Differ $\mathrm{T}$ and Favier I J $1990 \mathrm{~J}$. CFyst. Growth 106426

International Centre lor Diffaction Data 1994 Card No. 6-208, p. 327; NBS circular 539 (1955) p. 73

Jung $\mathrm{Y}$ J, Park M K, Tae S I, Lee K H and Lee H J 1991 I. Appl. Phys. 693109

Kim K M 1978 J. Cryst. Growth 44413

Lee $G S$, Thomson $P$ E, Davis J L, Omaggio $M K$ and Sehidt W A 1993 Solid State Electron. 36387

Lin $\mathrm{M} \mathrm{H}$ and Kou S $1995 \mathrm{~J}$. Cryst. Growth 152256

Look D C 1990 J. Electrochem. Soc. 137260

Michel E, Singh G, Slivkeen S, Besikci $C$ and Bove P 1994 Appl. Phys. Lett. 653338

Morrwood A F 1993 SPIE Int. Soc. Opt. Eng. 1946461

Mulski $\mathrm{G}$ and Neumatin $\mathrm{G} 1982 \mathrm{~J}$. Cryst. Growth 59548

Ohaski T 1986 J. Vatc. Sci. Technol. B4 622

Potart C 1981 d. Coyt. Growth 54558

Rayners J et al 1993 SPIE Int. Soc. Opt. Eitg. 1946490

Straus A J 1959 .J. Appl, Phys. 30559

Vaл der Pauw L J 1958 Philips Res. Reporl 13, pp 1-9

Witt A F and Galos H C 1968 J, Electrochen. Soc. 11570

Webor W, Noumanin G and Muller G $1990 \mathrm{~J}$. Cryst. Growth $100 \quad 145$

Zhou J L, Wiloox W R and Regel L L 1993 f. Cryst. Growth 128173 